\title{
VOJENSKÁ REFORMA V KONTEXTE BEZPEČNOSTNEJ POLITIKY RUSKEJ FEDERÁCIE
}

\section{MILITARY REFORM IN CONTEXT OF SECURITY POLICY OF THE RUSSIAN FEDERATION}

\author{
Martin HOREMUŽ*
}

\begin{abstract}
Abstrakt
Článok sa snaži približit' priebeh vojenskej reformy v Ruskej federácii v kontexte jej vlastnej bezpečnostnej politiky. V tomto zmysle sa zameriava predovšetkým na hlavné črty a problémy, s ktorými bolo reformovanie ozbrojených síl RF spojené. Základným nevyhnutným východiskovým bodom vojenskej reformy sa stala zmena medzinárodného bezpečnostného prostredia po rozpade bipolárneho systému, a taktiež vnútorná transformácia politického a ekonomického systému, ktorá však po roku 1991 prebiehala $v$ špecifických podmienkach poznačenými permanentnou ekonomickou a sociálnou krízou, kreovaním nového politického systému, hladaním postimperiálnej identity a miesta v systéme medzinárodných vztahov.
\end{abstract}

\begin{abstract}
The article analyzes the Russian military reform in context of security policy of the Russian Federation after the Soviet Union break up in 1991. In this connection it observes main features and problems connected with the military reform. Crucial for this period were wide changes in the international security environment (break up of bipolar system of international relations), which had a direct influence on redefinition and new formation of security politics of many countries, including Russia. On the other hand, this period meant specific conditions for the Russian Federation, during which the country was internally confronted with economy transformation effected during the whole period of the 90's by permanent economical and social crises, creating of a new political system and searching of its post-imperial identity in the system of international relations.
\end{abstract}

\section{Klíčová slova}

Transformácia globálneho bezpečnostného prostredia, vojenská reforma, bezpečnostná politika, ozbrojené sily Ruskej federácie, vojna v Čečensku a Gruzínsku.

\section{Keywords}

Transformation of global security environment, military reform, security policy, military forces of Russian federation, war in Chechnya and Georgia.

\section{ÚVOD}

Podl'a teórie realizmu ako teoretického prístupu v oblasti medzinárodných vzt’ahov sa kvalita národnej bezpečnosti každého štátu tradične viaže predovšetkým na ozbrojené sily krajiny, a to aj napriek tomu, že takýto vzt'ahový rámec uvedených dvoch premenných kategórií predstavuje len tzv. užšiu interpretáciu (národnej) bezpečnosti, ktorá má omnoho širšie súvislosti a konotácie. V širšom poňatí národnú bezpečnost' zaručuje štát (vláda) a zahíňa vstupy a účast' ministerstiev a d’alších ústredných orgánov štátnej správy, ale aj záujmových skupín a organizácií, ktoré sa

*E-mail: martin.horemuz@centrum.cz 
týkajú procesu kreovania (národnej) bezpečnosti v oblastiach ekonomickej, vojenskej, politickej, diplomatickej a právnej moci. Bez ohl'adu na kvalitatívnu zmenu medzinárodno-politických pomerov po skončení studenej vojny, ozbrojené sily štátu stále symbolizujú národnú obranu, resp. jej politicko-vojenskú dimenziu. Hoci miera vojenskej moci je dôležitá pri vývoji a komparácii medzi štátmi, takéto hodnotenie je potrebné vždy vel'mi opatrne interpretovat' (krajiny možno posudzovat' nielen podl'a vojenských kritérií - vel'kost' ozbrojených síl, počet zbraní rôzneho typu, výška finančných prostriedkov vynakladaná na výskum a vývoj nových vojenských technológií ale aj podl'a iných kvantitatívnych parametrov - ekonomických kritérií. ${ }^{1}$ Najčastejšie uvádzaným údajom, ktorý môžeme považovat' za relevantný a smerodajný, je percentuálny podiel z HDP, ktorý príslušný štát vydáva na obranu a bezpečnost'. Nie menej dôležitým aspektom v tomto smere je aj tzv. kvalitatívny rozmer (dimenzia), ktorý v súčasnosti predstavuje stav a úroveň vojenského obranného a bezpečnostného sektora.

$\mathrm{Na}$ proces vojenskej reformy bezprostredne vplýva stupeň, úroveň a rozsah bezpečnostnej politiky štátu, ktorá by mala vojenskú reformu implicitne zohl'adňovat' a obsahovo s ňou korešpondovat'. Bezpečnostnú politiku môžeme definovat' ako súbor štátnych opatrení v oblasti vonkajšej a vnútornej bezpečnosti štátu. V širšom význame spadá do bezpečnostnej politiky jednak ochrana štátu pred napadnutím zvonku, ale taktiež ochrana existujúceho štátneho zriadenia a právneho poriadku. V užšom význame zahrňuje predovšetkým ochranu bezpečnosti občanov a ich majetku. Podobný postoj zaujíma aj L. Frank, pričom upresňuje, že stanovenie zásad bezpečnostnej politiky je záležitost’ou zákonodarných orgánov štátnej moci, ich uskutočňovanie spadá do kompetencie vlády, najmä ministerstva vnútra, obrany a spravodlivosti. Bezpečnostná politika je najvyšší typ stratégie integrujúca zahraničnú a vnútornú politiku a obranu štátu. ${ }^{2}$

Pre ruské reálie je relevantné, že bezpečnostná politika, resp. proces formovania a tvorby bezpečnostnej politiky až po finálne decízno-realizačné štádium sa po formálnej stránke uskutočňuje prostredníctvom inštitucionálnej bázy (aj ked' samotný jej proces nemožno nazvat' pevne inštitucionalizovaný), ktorú tvoria: orgány zákonodarnej, výkonnej a súdnej moci, štátne, spoločenské a iné organizácie a inštitúcie, ale aj občania, prijímajúci účast' v zaistení bezpečnosti v súlade so zákonom, a taktiež normatívno-právne akty regulujúce vzt'ahy v sfére bezpečnosti. Spoločné riadenie štátnych orgánov pre zaistenie bezpečnosti uskutočňuje prezident Ruskej federácie (RF), ktorý predsedá Rade bezpečnosti RF (RB RF) (členmi RB RF sú predseda vlády RF tzv. siloví ministri - minister vnútra RF, minister obrany RF (MO RF), šéf Federálnej bezpečnostnej služby RF, a tajomník menovaný prezidentom RF). Ďalšími orgánmi sú vláda RF, ministerstvá a štátne výbory RF. ${ }^{3}$ Svoj neformálny, a na ruské reálie nezanedbatel'ný vplyv na tento proces majú aj rôzne záujmové skupiny, dotvárajúce kolorit každého politického systému (predovšetkým vojensko-priemyselný komplex). Ozbrojené sily Ruskej federácie (OS RF) predstavujú mocenský nástroj štátu, ktorých ciel’om je predovšetkým zaistenie bezpečnosti, suverenity a územnej celistvosti ruského štátu.

Aj ked' krátky pohl'ad do histórie ukazuje, že ruská armáda sa vlastne nikdy nestala subjektom politiky ako takej, jej váha ako bezpečnostného faktora v ruskej tradícii však vždy sám osebe predurčoval mimoriadnu úlohu armády v politike ruského (neskôr sovietskeho a potom opät' ruského) štátu. Od petrovskej doby všetky inštitúcie, zdroje a privilégiá boli podriadené potrebám armády, ktorá sa stala politickou a sociálnou silou so svojimi vlastnými právami. V dôsledku obrovských nárokov kladených na ruské finančné, technologické a produktívne zdroje armáda taktiež dominovala v ekonomike. Táto dominancia sa iracionálnou formou prejavila najmä počas existencie Sovietskeho zväzu, ked' vo svojej vnútornej imanencii bola militarizovaná celá spoločnost'. Napriek tomu, že militarizácia sovietskej spoločnosti bola pochopitel'ne značne spojená s pôsobením armády, rozhodne to neznamenalo, že armáda spoločnost' bezprostredne ovládala. Totalitný systém takúto možnost' nepripúšt’al. Aj ked' armáda predstavovala dôležitý nástroj vládnucej strany, resp. elity, armáda vždy disponovala silnou autoritou na to, aby najvyšší stranícky a štátni predstavitelia brali na jej názory ohl’ad. Narušenie tohto neformálneho princípu sa 
nepripúšt’alo a nebolo akceptovatel'né ani to, aby armádni činitelia mali väčšiu autoritu ako komunistická strana. ${ }^{4}$

\section{ZDROJE RUSKEJ VOJENSKEJ REFORMY}

Výrazné medzinárodno-politické zmeny, ktoré sa odohrali koncom 80. a začiatkom 90. rokov 20. storočia, sa prirodzene bezprostredne dotkli aj sovietskych (resp. ruských) ozbrojených síl. Reforma ozbrojených síl, resp. vojenská reforma ako jedna zo základných tém diskusií v ruských politických, vojenských a odborných kruhoch je v centre pozornosti od začiatku 90. rokov 20. storočia - rozpadu Sovietskeho zväzu, ktorý znamenal vznik samostatných OS RF. Ich faktickú existenciu možno datovat' od 7. mája 1992. O problematike vojenskej reformy (pre obdobie posledného decénia minulého storočia by bolo adekvátnejšie skôr použit' termín nereformy vzhl'adom na reálny rozsah uskutočnených a realizovaných opatrení, ktoré reformou nebolo možné nazvat') bolo v ruských periodikách, odborných a analytických časopisoch publikovaných množstvo článkov, analýz a vedeckých štúdií. Čo je však smerodajnejšie, pre skúmanie problematiky vojenskej reformy v RF mali rozhodujúcu váhu niektoré dôležité politické, sociálne a hospodárske udalosti, v rámci ktorých proces vojenskej reformy prebiehal, a ktoré boli jednak ruskému štátu vlastné (špecifické), ale aj udalosti, ktoré mali širšie medzinárodno-politické dopady a postihli globálne bezpečnostné prostredie postbipolárneho obdobia. V súvislosti s vojenskou reformou v RF je nevyhnutné spomenút' predovšetkým:

\section{a) Rozpad ZSSR a komunistického systému}

Pre oblast' bezpečnostnej politiky a jej neskorší vývoj, resp. z hl'adiska obsahovej stránky bolo nevyhnutné, aby vojenská reforma objektívne reflektovala udalosti 90 . rokov minulého storočia, ktoré znamenali zánik bipolárneho usporiadania medzinárodného politického systému, založeného na ideologickej konfrontácia a existencii dvoch supervel'mocí (ZSSR a USA), resp. vojensko-politických blokov (Varšavská zmluva a NATO) garantujúcich pomocou vzájomne zaručeného zničenia (Mutual assued destruction) existujúci status qou pomerov v rámci vlastných mocenských blokov. 5

\section{b) Transformácia globálneho bezpečnostného prostredia}

Vývoj po roku 1990 predstavoval nielen obdobie zásadných zmien na politickej mape sveta a v štruktúre medzinárodných vzt’ahov, ale je charakterizovaný aj výraznými štrukturálnymi premenami odzrkadl'ujúcimi sa vo vnímaní a interpretácii bezpečnosti, bezpečnostných hrozieb a rizík, resp. formulovaní a kreovaní bezpečnostnej politiky jednotlivých štátov (vrátane RF) a medzinárodných regionálnych organizácií (NATO, EÚ, OBSE). Tieto radikálne premeny sú výsledkom nových geopolitických pomerov (ukončenie studenej vojny, rozpad komunizmu, rozpad Sovietskeho zväzu a z toho vyplývajúci vznik nových nezávislých štátov, rozširovanie NATO o štáty bývalého sovietskeho bloku), ale najmä štrukturálneho narastania a prehlbovania vzájomných interakcií (interdependencie) v rámci medzinárodného systému (politického, hospodárskeho, bezpečnostného), a to nielen medzi suverénnymi štátmi na bilaterálnej, ale aj $\mathrm{v}$ rámci medzinárodných a regionálnych organizácií na multilaterálnej úrovni. V medzinárodnom meradle je pregnantná výrazná tendencia k transformácii bezpečnostných rizík a zdrojov ohrozenia. Výsledkom tejto metamorfózy je nadobúdanie čoraz väčšieho významu tzv. soft security, ktorá v sebe integruje hrozby a riziká nevojenského charakteru. Bezpečnostné hrozby a riziká postbipolárneho obdobia sa stali početnejšie, diverzifikovanejšie, rôznorodejšie, rozdielnej dôležitosti a intenzity. Vonkajšie hrozby a riziká sa môžu vo svojich dôsledkoch kombinovat' s hrozbami a rizikami vo vnútri krajiny. Ich zdrojom sú dnes vo vel'kej miere neštátne subjekty (non-state actors), ktoré nerešpektujú medzinárodné záväzky, normy a princípy. Súčasne sa uskutočňuje transformácia významu jednotlivých aspektov bezpečnostnej politiky. 


\section{c) Politická, ekonomická a spoločenská transformácia RF}

Situáciu okolo vojenskej reformy po roku 1991 silne komplikovala situácia v RF, ktorú možno charakterizovat' ako hlbokú ekonomickú a sociálnu krízu (treba poznamenat', že tá bola prítomná už v čase existencie ZSSR pred rokom 1991, rozpadom komunistického systému však akcelerovala). Táto kríza zasiahla všetky odvetvia ruského štátu a spoločnosti, armádnu a vojenskú oblast' nevynímajúc. Armáda, ako inštitúcia sa v tomto čase neustále konfrontovala s hospodárskymi t’ažkost’ami, pretože bola ekonomicky so štátom silne previazaná (v dôsledku existujúcej centralizácie a byrokratizácie), resp. finančne závislá (v dôsledku gigantických dotácií a priamych a nepriamych subvencií).

\section{d) Vojenský konflikt v Čečensku}

Predstavy a názory o konkrétnych krokoch a hĺbke vojenskej reformy sa v počiatočných rokoch existencie RF dost' výrazne odlišovali. Otázka v tomto čase nestála či vôbec armádu reformovat', ale akým spôsobom a v akom rozsahu. Nevyhnutnost' presadenia vojenskej reformy potvrdzoval aj neúspešný pokus o štátny prevrat v auguste 1991 iniciovaný konzervatívnym krídlom komunistickej strany. Neúspešný pokus o prevrat znamenal pre politický establišment jeden zásadný záver - armáda musí stát mimo politiku tak, aby nebola v rámci politického boja zneužitá pre záujmy akejkol'vek politickej sily alebo skupiny. Neskôr v októbri 1993 armáda asistovala pri rozstriel'aní Najvy̌šsieho sovietu (tzv. jesenná vojna). V procese právneho a ústavného konštituovania RF sa $\mathrm{v}$ tomto čase stalo kl'účovou úlohou pre vtedajšie politické vedenie štátu na čele s prezidentom Borisom Jel’cinom, aby sa armáda ako inštitúcia plne stotožnila s existenciou nového demokratického Ruska. Na druhej strane to bol práve prezident Jel'cin a úzka skupina l'udí v jeho okolí, ktorý sa rozhodol prijat dodnes kontroverzné politické rozhodnutie vojensky riešit’ situáciu Čečenskej republiky v roku 1994. Výsledkom obidvoch konfliktov sa stal silne narušený obraz a prestíž armády doma a v zahraničí. Okrem toho vojenská operácia v Čečensku naplno odhalila slabiny OS RF, a ich jednotlivých zložiek (pozemnej, leteckej) v reálnom boji.

\section{OBDOBIE ,PERMANENTNEJ KRÍZY“ - PRIEBEH VOJENSKEJ REFORMY V ROKOCH 1992-1999}

RF zdedila po bývalom ZSSR takmer štvormiliónové ozbrojené sily. Tento kolos bol pre Rusko ako nový štát, zmietajúci sa vo vážnych hospodárskych a vnútropolitických t’ažkostiach, absolútne neúnosný. Samozrejme, že proces akejkol'vek reformy je v prvom rade otázka finančná. Z tohto titulu aj realizácia vojenskej reformy bola hned' od začiatku podmienená rozpočtovými možnost’ami RF. V roku 1991 bol percentuálny podiel na obranu v pomere k HDP 11,1 \% (údaje za celý ZSSR), roku 1992 4,5 \%, 1993 4,8 \%, 1994 6,6 \%, 1995 3,71 \%, 1996 3,76 \%. ${ }^{6}$ Na roky 1998-2003 bola síce ako optimálna výška obranných výdavkov stanovená prezidentskými dekrétmi úroveň 3,5 \% HDP, ale v rámci federálneho rozpočtu dosahovala v skutočnosti 2,4 až 2,7 \% HDP (v roku $20032,7 \%$ HDP). ${ }^{7}$ Zároveň treba podotknút', že na vojenské operácie v Čečensku (tzv. prvá čečenská vojna) bolo podl'a niektorých odhadov z rozpočtu RF vyčlenených 1,4 bilióna USD. ${ }^{8}$ Rozpadom ZSSR sa ruská spoločnost' dostala do stavu hlbokej a permanentnej sociálnej a ekonomickej krízy (v RF označovanej ako „smutnoje vremja“ alebo aj čas chaosu), ktoré charakterizovalo obdobie 90. rokov. ${ }^{9}$ Problematickým z pohl'adu vojenskej reformy sa stávala neschopnost' vyrovnat' sa zo skutočnost'ou, že reforma ozbrojených síl by okrem iného mala predstavovat' aj mentálno-psychologickú dimenziu spočívajúcu v oslobodení sa od starého myslenia, v ktorom bol akcent kladený na tradičné chápanie bezpečnosti - hard security (vel'ké ozbrojené sily, dôraz na jadrový faktor), nerešpektujúce aktuálnu medzinárodno-politickú situáciu (nepravdepodobnost' globálneho konfliktu, formovanie nových partnerských vzt'ahov medzi NATO a RF) a bolo symptomatické v období 90 . rokov minulého storočia nielen v politických kruhoch, 
ale najmä varmáde a vojensko-priemyselnom komplexe (Vysokí konzervatívne orientovaní vojenskí predstavitelia armády sa obávali o svoju pozíciu a privilegované postavenie armády ako inštitúcie. V konečnom dôsledku sa tento postoj prejavil aj v silnom odpore k vojenskej reforme. VPK nemal o takúto reformu záujem, naopak presadzoval svoje ekonomické záujmy, ktoré súviseli so zachovaním objemu štátnych obranných zákaziek v oblasti nákupu vojenskej techniky).

Nemenej zaujímavý pohl'ad, ktorým možno dokumentovat' stav a vývoj vojenskej reformy v prvých rokoch demokratického Ruska možno objavit' v analytickej štúdii s názvom: „Vojenská reforma vRuskej federácii: Východisko na praktickú úroveñ potrebuje spresnenie cielov a možností “ vydanej v roku 1999 Inštitútom národnej bezpečnosti a strategických štúdií. Kolektív autorov v tejto štúdii operuje s pojmom ideológia, resp. potvrdzuje existenciu ideologického rozmeru, s ktorým je podla autorov inštitútu inherentne problematika vojenskej reformy spojená (spolu s inými spoločensko-politickými oblast’ami). Jednou z príčin krízy je implicitne uvedená deideologizácia, ktorá vraj priniesla do ruskej armády mnoho neštastia: „Vec bez viery je mŕtva. Podl'a nášho názoru, v danom momente vojenská reforma v Ruska má velmi slabé ideologické zabezpečenie ". ${ }^{10}$ Uvedené konštatovanie dokonca vedie autorov tejto štúdie k záveru, že medzi nevojenské hrozby, okrem ekonomických a politických zarad'ujú aj ideologické. Naopak korektne formulujú predpoklad, že momentálne existujúce vonkajšie podmienky sú priaznivé na uskutočnenie vojenskej reformy, ktorú pokladajú len za jednu z častí komplexného reformovania štátu, spoločnosti a jej štruktúr. V tomto rozsiahlom materiály sa vodstate potvrdzuje nevyhnutnost' vojenskej reformy, ktorá by mala spočívat' $v$ troch rozmeroch: ekonomickom, technologickom a geopolitickom. Aj ked' autori vel'mi správne upozorňujú na nevojenské hrozby (terorizmus) a riziká plynúce $\mathrm{z}$ lokálnych konfliktov (prevažne v postsovietskom priestore), napriek tomu sa niektoré ich odporúčania javia neaktuálne a v niektorých smeroch aj nereálne. ${ }^{11}$

Samotný stav ruských ozbrojených síl bol v prvej polovici 90. rokov 20. storočia poznačený predovšetkým neúspešnou vojenskou operáciou v Čečensku (1994-1996), ktorá fakticky potvrdila jej nebojaschopnost' a zastaranú technickú vybavenost', a tým naplno odhalila hlboké vnútorné štrukturálne problémy, nehovoriac už o morálných aspektoch problému (dezercia, týranie vojakov - tzv. „dedovščina“, samovraždy). ${ }^{12}$ Vel’mi vážnym sa v počiatočnom období javil problém okolo sociálnych náležitostí (bytová politika) predovšetkým vojakov odsunutých zo štátov strednej a východnej Európy, aj ked' nedostatok vhodných bytov sa týkal aj vojakov slúžiacich na teritóriu RF a prakticky dodnes nie je vyriešený podl'a predstáv politických a vojenských predstavitel'ov. Úpadok armády v ruskej spoločnosti ako inštitúcie dokumentovala aj výrazne nízka ochota a vôla vykonávania základnej vojenskej služby medzi mladými odvedencami, ktorý sa čoraz častejšie vyhýbali odvodovým povinnostiam. V transformovanej ruskej spoločnosti už služba $\mathrm{v}$ armáde nemala taký honor, ani čest' ako v období ZSSR a naviac ako profesia nebola ani dostatočne platovo ohodnotená (čo platí dodnes). Vel'mi výrazným problémom v armáde ako aj celej ruskej spoločnosti je vysoká miera korupcie, kriminality (vrátane organizovaného zločinu) a alkoholizmu.

\section{KONSOLIDÁCIA RF - VOJENSKÁ REFORMA PO ROKU 2000}

Pre odborné štúdie a články, ktoré sa zaoberajú zahranično-politickým, bezpečnostným, vnútropolitickým a hospodárskym vývojom v RF po roku 2000 sa čoraz častejšie stretávame s termínom tzv. vertikály moci. Vertikála moci predstavuje vnútorné politické, inštitucionálne, hospodárske a administratívne usporiadanie štruktúry ruského politického systému (štátu), ktorý sa vyznačuje centralizačnými a kontrolnými tendenciami s priamym dosahom na celú ruskú spoločnost'. Upevnenie tejto vertikály moci sa stalo pregnantným znakom vládnutia prezidenta V. Putina. Už v máji roku 2000 V. Putin rozdelil územie RF na sedem supraregiónov (administratívnych okruhov). Na čele každého takéhoto supraregiónu bol vymenovaný prezidentov zmocnenec, ktorý je zodpovedný priamo prezidentovi RF. Úlohou zmocnencov prezidenta RF bolo na zverenom území koordinovat' výkon federálnej správy, rozdel'ovat' peniaze z centra a dohliadat' na to, ako si počínajú regionálni prezidenti, gubernátori a šéfovia oblastí. V tejto súvislosti treba 
uviest', že určite nebolo náhodou, že tieto administratívne okruhy sa teritoriálne takmer stotožňujú s rozdelením RF na vojenské okruhy. ${ }^{13}$ Čo je nemenej zaujímavé, zo siedmych zvláštnych prezidentských zmocnencov až piati mali hodnost' generála, a pochádzali z radov bývalej KGB alebo armády. Prvoradým ciel’om na ktorý sa V. Putin od začiatku svojho funkčného obdobia zameral boli kroky, ktoré jasne signalizovali plány na obnovenie vojenskej moci RF. Tieto sa stali počas výkonu prezidentského mandátu (2000-2008) jednou z priorít realizovanej politickej agendy. V tomto ohl'ade je však nástup V. Putina k moci spájaný aj so zlepšením financovania armády a VPK, k čomu okrem iného napomohli predovšetkým vysoké ceny ropy a plynu na svetových trhoch.

Po roku 2000 už nikto nepochyboval o tom, že ruské ozbrojené sily nevyhnutne musia prejst' skutočnou reformou a transformáciou, resp. redefiníciou $\mathrm{z}$ hl'adiska jej zadefinovaných úloh a ciel'ov. Takémuto hodnoteniu zodpovedalo aj prijatie základných doktrinálnych dokumentov ruskej zahraničnej a bezpečnostnej politiky v prvej polovici roku 2000, čím došlo k prehodnoteniu pôvodných doktrinálnych dokumentov z 90 . rokov 20 . storočia. ${ }^{14}$

Je prirodzené, že vojenská reforma musí v prvom rade byt' v úzkej symbióze so základnými doktrinálnymi dokumentmi ruskej bezpečnostnej a zahraničnej politiky. Tieto dokumenty totižto definujú nielen základné a životne dôležité národné, bezpečnostné a ekonomické záujmy, ale predovšetkým pomenovávajú existujúce (potenciálne) hrozby a riziká (vojenského aj nevojenského charakteru), na ktoré musí byt' v budúcnosti ruské obranné a bezpečnostné plánovanie pripravené. Ich správne identifikovanie a pomenovanie je kruciálnym predpokladom pre úspešné vykonanie vojenskej reformy. To, že otázka bezpečnosti, ako jedného z kardinálnych aspektov národných záujmov štátu zahŕňa v sebe vel'mi dôležitú otázku vojenskej reformy, resp. to že existuje determinačná interakcia medzi jasne definovanou a čitatel'nou koncepciou národnej bezpečnosti a reformou armády ako inštitúcie, vyjadril ešte v roku 1998 aj bývalý tajomník Rady bezpečnosti Ruskej federácie Ivan Rybkin „existuje vel'mi dôležitý aspekt o ktorom sa málo hovorí a ktorý spočíva v tom, že bez uceleného pohl'adu na národnú bezpečnost' t’ažko uskutočnit' vojenskú reformu. “15 Aj ked' reálny obraz vojenskej reformy a diskusie s ňou spojené v priebehu 90. rokov minulého storočia pripomínali „prešlapovanie na mieste“, zvolenie V. Putina za prezidenta RF vrátilo debatu o reforme armády do centra pozornosti, pretože skutočná reforma sa podl’a odborného hodnotenia do roku 2000 ani nezačala, čo potvrdzujú nielen výroky niektorých ruských politikov, mimo iných aj prezidenta RF, ale aj oficiálny doktrinálny dokument z roku 2000 Vojenská doktrína Ruskej federácie (VD RF): „Prioritnou úlohou a súčastou súčasnej etapy vojenskej výstavby je uskutočnenie komplexnej vojenskej reformy, podmienenou radikálnymi zmenami vojensko-politickej situácie, úloh a podmienok zabezpečenia vojenskej bezpečnosti RF “. ${ }^{16}$ O niekol'ko mesiacov po prijatí VD RF v rozhovore pre Le Figaro prezident RF V. Putin potvrdil význam uskutočnenia vojenskej reformy, ked' uviedol: „Reforma armády je jednou z ruských priorít. Chceme udržat' našu bezpečnost' na maximálnej úrovni. Je to priorita priorít. Preto je potrebná reforma, kvôli tomu je potrebné zlepšenie štruktúry. “17 Podl'a odborných hodnotení (P. Felgengauer) bola v tomto čase (2002) hlavná príčina neúspechu vojenskej reformy vo vysokých a starších vojenských dôstojníkoch, ktorí boli po odbornej stránke pripravení v sovietskom období, a v súčasnosti obracajú pozornost' na sovietsku armádu, ktorú sa pokúšajú v rôznej podobe ,vzkriesit““. ${ }^{18}$ Schopnost' a vôl'u presadit' naštartovanie vojenskej reformy malo v tom čase pomôct' aj vymenovanie Sergeja Ivanova za MO RF, ktorý ešte vo funkcii tajomníka RB RF (1991-2001) demonštroval odhodlanie dôsledne realizovat' úlohy tohto náročného procesu, aj ked' o jeho úspechoch reálne riešit' pálčivé otázky spojené s vojenskou reformou sa dá polemizovat'. Okrem iného (v čase výkonu spomínanej funkcie) presadil zriadenie Komisie pre vojenskú reformu, ktorá do tej doby postupovala značne nekoordinovane a chaoticky. To, že vojenská reforma sa do roku 2000 v podstate nezačala potvrdzovali vyjadrenia najvyšších politických predstavitel'ov. Napr. 7. decembra 2001 vtedajší premiér Michail Kasjanov uviedol, že zatial' nie sú určené lehoty vojenskej reformy, pretože jej realizácia môže trvat' do roku 2010, ale nevylúčil možnost' aj jej skoršieho dokončenia. Taktiež uviedol, že v roku 2003 sa začne 
experiment s kontrakčným systémom a prechod na tento systém bude ukončený (konkrétne sa jednalo o experiment so 76. vysádkovou divíziou v Pskovsku - pozn. autor) do roku 2004. Nevyhnutnost' čo najskoršieho uskutočnenia vojenskej reformy potvrdil opätovne prezident V. Putin aj vo svojom každoročnom posolstve Federálnemu zhromaždeniu RF (FZ RF) 16. mája 2003, kde modernizáciu ozbrojených síl, spolu s bojom proti terorizmu a rastom ekonomiky, označil ako jednu z troch priorít. Napriek uvedeným výrokom v praxi sa bolo v tomto čase možné stretnút' s mnohými antagonistickými krokmi, ktoré vojenskú reformu redukovali na aspekt materiálnotechnického vybavenia OS RF, a potláčali do úzadia kvalitatívnu stránku reformy, najmä aspekty riadenia a velenia, plánovania a prípravy armádnych štruktúr.

Jedným zo základných znakov ruskej vojenskej reformy by mala byt' aj profesionalizácia armády. Prezident V. Putin na zasadnutí RB RF 31. mája 2002 uviedol, že na báze leteckovýsadkových vojsk začatý experiment kompletizovania vojsk na zmluvnom princípe (ktorý však narážal na odpor Generálneho štábu RF) bude zabezpečený dôsledný prechod ozbrojených síl na tento princíp. V už zmienenom prejave FZ RF v roku 2003 uviedol, že v ohniskách napätia a lokálnych konfliktov musia byt' nasadzované len profesionálne jednotky. Ciel'om sa stalo, aby poloprofesionálna armáda začala fungovat' $\mathrm{v}$ roku 2007, resp. začiatkom roka 2008. Profesionalizácia ozbrojených síl, podobne ako celá vojenská reforma, však vyžaduje aj optimalizovanie (zníženie) početných stavov v ozbrojených silách. Niet pochýb o tom, že redukcia vojenského, ale aj civilného personálu v ruských ozbrojených silách je nevyhnutná. Napriek tomu prezident V. Putin 2. októbra 2003, pri príležitosti oficiálneho predstavenia doktrinálneho dokumentu Aktuálne úlohy ozbrojených síl RF vyhlásil, že Rusko už nechystá d’alšie zníženie stavu svojich ozbrojených síl - priamo v tomto dokumente sa uvádza, že k 1. 8. 2003 bolo v ozbrojených silách 1,16 mil. osôb a ku koncu roka sa má stav stabilizovat' na 1 mil.. ${ }^{19} \mathrm{Je}$ však vysoko pravdepodobné, že skutočná úroveň bola v tomto období úplne iná (údaje sa v tomto smere značne líšia). V roku 1998 počet vojakov v ruských ozbrojených silách predstavoval 1,7 mil.. ${ }^{20} \mathrm{Na}$ konci roka 2000 bolo plánované dosiahnut' stav 1 mil. Podl'a niektorých údajov v priebehu rokov 2005-2006 mali ozbrojené sily RF 1 mil. mužov v zbrani. ${ }^{21}$ A. Arbatov však uvádza, že znižovanie počtu vojakov uviazlo na hranici 1,1-1,2 mil.. ${ }^{22}$ RF si však podl'a expertov takúto vel'kú armádu nemôže z finančných dôvodov dovolit', a aj preto bolo vyhlásenie V. Putina o pozastavení znižovania stavu ozbrojených síl vel'mi prekvapujúce. V tejto súvislosti ruský bezpečnostní experti hovorili o troch variantoch kvalitatívnej úrovne ozbrojených síl: 1.) 550-600 tis., 2.) 700-750 tis., 3.) 800-850 tis.. Aj o uvedených návrhoch sa však v médiách vel'mi široko polemizovalo. Ked’že momentálne nie je k dispozícii spol’ahlivý a presný údaj o počte vojakov (podla vyjadrenia MO RF Anatolija Serdjukova z 14. októbra 2008 predstavuje početný stav ruskej armády 1109 tis. osôb), predpokladá sa, že je stále vyšší ako 1 mil.. Taktiež si treba uvedomit', že do uvedených počtov nie sú zahrnuté d'alšie druhy vojsk, ktoré kompetenčne nespadajú pod MO RF, a ktorých znižovanie tabul'kových počtov prebiehalo $\mathrm{v}$ tom istom čase $\mathrm{s}$ rozporuplnými výsledkami. Jedná sa predovšetkým o niektoré ministerstvá, ústavy a d’alšie štátne štruktúry agentúrneho charakteru (Federálna bezpečnostná služba RF, Ministerstvo vnútra RF, Ministerstvo pre mimoriadne situácie RF, Železničné vojsko RF, pohraničné sily RF, vojenská rozviedka a iné).

Vojenská reforma v sebe integruje širokú škálu otázok. Okrem zmieneného prechodu armády na kontraktačnú bázu, je vojenská reforma spojená predovšetkým s modernizáciou zbraňových systémov a vojenského vybavenie, so sociálnymi otázkami dôstojníkov a vojakov. Ďalším krokom, ktorý bol hodnotený ako súčast' vojenskej reformy, sa stala optimalizácia druhovej štruktúry ozbrojených síl. Na realizáciu tejto úlohy bol uskutočnený prechod na trojdruhovú štruktúru ozbrojených síl: pozemné vojská, vzdušné sily, námorné sily. Raketové vojská strategického určenia sa zreorganizovali v druh vojsk ozbrojených síl, pričom z ich zostavy boli vyčlenené vojská raketovo-kozmickej obrany a kozmické sily a prostriedky. Na ich základe sa sformoval nový druh vojsk - Kozmické vojská RF. Posledným druhom vojsk sú letecko-výsadkové vojská. Osobitné miesto majú tylové ozbrojené sily, ktoré však nie sú druhom ozbrojených síl. Taktiež došlo k zníženiu počtu vojenských obvodov z 8 na 6 (Kaliningrad zostal špeciálnym regiónom). Ako 
však poznamenáva M. Orr, reagujúc na skúsenosti so zlučovaním vojenských obvodov a navrhovania štruktúr ozbrojených síl ešte pred rokom 2000: „štrukturálne zmeny sú najlahšou čast’ou reformy, pretože sa dotýkajú problémov, ktoré je možné riešit' dekrétmi ministra obrany. Skutočné problémy, ktorým čelia ruské ozbrojené sily, nemôžu byt' vyriešené papierovými rozkazmi a dotýkajú sa faktorov mimo dosahu ministerstva obrany. “23 $\mathrm{Aj}$ z uvedeného bolo možné usudzovat', že realizované kroky v rámci reformy sa napriek venovanej pozornosti javili ako nedostatočné a málo razantné, resp. nemali dostatočnú híbku. 30. marca 2004 v tlačovom centre RIA Novosti to v podstate potvrdil aj predseda Rady pre zahraničnú a obrannú politiku (SVOP) Sergej Karaganov, ked' predstavil krátky variant dokumentu s názvom: „Vojenská výstavba a modernizácia Ozbrojených síl Ruska“. Autori tohto dokumentu sa nazdávajú, že nie všetky procesy, ktoré prebiehajú v ozbrojených silách je možné považovat’ za prestavbu (perestrojku) vojenského aparátu, a trvali na hlbokej reforme armády, súčasne s radikálnou reštrukturalizáciou VPK, nakol'ko tieto kroky sú vzájomne podmienené. ${ }^{24}$

Čo však nemožno prehliadnut' je fakt, že zvolenie V. Putina za prezidenta RF na druhé funkčné obdobie (2004-2008) predstavovalo v procese vojenskej reformy určitú záruku a kontinuitu (pre vysokú vojenskú elitu), že pozornost' venovaná zlepšeniu postavenia armády, jej modernizácii a premene na silný mocenský nástroj ruského štátu, zostane aj počas jeho druhého volebného obdobia prioritnou úlohou. $\mathrm{V}$ tomto smere nedošlo $\mathrm{k}$ zásadnej zmene, ktorá by narušila postupné petrifikovanie neprimeraného postavenia a pozícií silových štruktúr v ruskej spoločnosti. Na druhej strane tento stav naznačoval, že personálne obsadenia v najvyšších politických a armádnych postoch zaväzovalo V. Putin (a jeho nasledovníka) do budúcnosti brat' ohl'ad aj na názory vysokých armádnych kruhov a vplyvných lobistických skupín (palivovo-energetický sektor, VPK), aby nestratil ich podporu a lojalitu. To môže vysvetl'ovat' prečo nebola vojenská reforma od svojho počiatku tak razantná a jednoznačná, resp. bola poznamenaná doterajšími rozporuplnými prvkami, ktoré čiastočne poznačili smerovanie reformy. Najpodstatnejšie je, že nevyhnutnost' reformovania armádneho sektora v RF momentálne nikto relevantný nespochybňuje, názorové diferenciácie sú len v spôsobe a hĺbke realizácie.

Za kl'účový doktrinálny dokument ruskej vojenskej a bezpečnostnej politiky, oficiálne predstavený 2. októbra 2003, možno považovat' už zmieňované: „Aktuálne úlohy rozvoja ozbrojených síl Ruskej federácie“, v ktorom sa reflektuje dynamika a zmeny bezpečnostného vývoja vo svete, ktoré sa bezprostredne dotkli aj RF. ${ }^{25}$ Nezávislý vojenský expert Pavel Fengengauer nazýva uvedený dokument „Ivanovou doktrínou“, pričom kriticky poznamenal jej byrokratický charakter, ktorý kombinuje západný zovňajšok so sovietskym obsahovým štýlom. Taktiež kriticky poznameáva, že uvedená doktrína je súhrnom predstáv a názorov MO RF, a za skutočnú vojenskú doktrínu ju nemožno považovat. ${ }^{26}$ Svojim spôsobom sa jedná o otvorenú doktrínu zameranú hlavne na modernizáciu OS RF, reštrukturalizáciu OS a na sumarizáciu aktuálnych hrozieb a výziev súčasnosti. ${ }^{27}$ Dokument sa zameriava najmä na nasledovné hlavné zmeny:

a) v chápaní pojmu obrana - od obrany územia smerom k obrane záujmov;

b) zmenu koncepcie vojny od klasickej na protiteroristickú;

c) na prevenciu a elimináciu politických a etno-politických konfliktov;

d) na zabezpečenie vnútornej situácie a stability krajín SNŠ a pril'ahlých regiónov. ${ }^{28}$

Aj ked' dokument poukazuje, že síce neexistuje priama vojenská hrozba, upozorňuje, že ruské vojenské plánovanie v oblasti rozvoja a použitia ozbrojených síl RF musí počítat' s množstvom faktorov neurčitosti, čo je taká situácia, konflikt alebo proces politického alebo vojenskopolitického charakteru, ktorého vývoj môže podstatne zmenit geopolitickú situáciu v prioritnom regióne záujmu Ruska alebo vytvorit' priamu hrozbu bezpečnosti RF.

Hodnotenie tohto doktrinálneho dokumentu ruskej bezpečnostnej politiky poukazuje na pretrvávajúcu tendenciu v oblasti ruského bezpečnostného prístupu, ktorý je svojim vnútorným 
obsahom a charakterom založený na akcentovaní tradičného (klasického) chápania bezpečnosti, v ktorom primárnu úlohu zohrávajú silné ozbrojené sily, a to aj napriek nepochybnému pomenovaniu a identifikovaniu nevojenských hrozieb a rizík. Dôležitým indikátorom je taktiež skutočnost', že vo všetkých ruských doktrinálnych dokumentoch má bezpečnost' a jej obsah výrazné štátno-centrické konotácie, t.j. bezpečnost' občana a spoločnosti je odvodzovaná od bezpečnosti štátu a nie naopak.

V závere tejto časti je potrebné $\mathrm{v}$ súvislosti s vojenskou reformou zmienit' konštituovanie Spoločenskej rady pri MO RF v auguste 2006. Tento orgán dohliada nad zákonmi a právnymi dokumentmi, ktorých iniciátorom je MO RF. Rada je zodpovedná za legislatívu bezprostredne sa dotýkajúcu vojakov a civilných zamestnancov MO RF, za podmienky vojenskej služby a aspekty zhoršujúce vojenskú disciplínu a vynútitel’nost’ práva. ${ }^{29}$

\section{VOJENSKÁ REFORMA - ROK 2008, AKO ĎALEJ?}

Zvolenie D. Medvedeva za prezidenta Ruskej federácie v prvom štvrt'roku 2008 a jeho doterajšie pôsobenie vo funkcii potvrdzuje, že najvyššie politické vedenie aj pod novým prezidentom pokračuje $\mathrm{v}$ politike svojho predchodcu, ktorý prikladal mimoriadny význam stabilizácii a zefektívneniu činnosti silových štruktúr. Silné pozície vojenských štruktúr (uniformovaných), ktoré sa dostali k moci počas éry V. Putina (súčasného premiéra RF), a ktorý si aj napriek odchodu z funkcie prezidenta RF ponecháva rozsiahly politický vplyv, zaručuje, že doterajšia pozornost' venovaná ozbrojeným silám a zlepšeniu postavenia armády, jej modernizácii zostanú nad’alej jednou z prioritných úloh. Vysoké prírastky HDP, ktoré Rusko po roku 2002 dosahovalo, a ktoré sú spojené najmä s výrazným rastom svetových cien energetických nosičov priniesli finančné prostriedky do rozpočtu, a následné zlepšenie financovania armády v oblasti sociálnych náležitostí vojakov, ale aj nákupu nových zbraní a vojenskej techniky. Hlavnou udalost'ou roka 2008 sa stal proces naštartovanej reformy OS RF, výsledkom ktorej by mala byt' kompaktná, vysoko mobilná, akcieschopná armáda schopná reagovat' na vzniknuté konflikty a zaistit' bezpečnost' ruského štátu a jeho občanov.

Rozhodujúce miesto a úlohu OS RF v procese zabezpečenia bezpečnosti RF priznáva aj nový doktrinálny dokument prijatý 13. mája 2009 s názvom ,Stratégia národnej bezpečnosti RF do roku 2020“. Tento dokument z hl'adiska svojho spracovania má ucelenejší a jednoznačne konkrétnejší (ale aj agresívnejší) charakter. Dôraz je kladený na vytváranie multipolárneho usporiadanie medzinárodného politického systému so zodpovedajúcim miestom pre RF. Osobitnú pozornost' $\mathrm{v}$ tejto súvislosti venuje oblasti kontroly nad prírodnými zdrojmi (energetickými surovinami), ktoré budú v budúcnosti základným atribútom prežitia (štátu, nadnárodných korporácií, ale aj jednotlivcov). Na ich hájenie sa v tomto smere nevylučuje ani možnost' použitia silových prostriedkov. ${ }^{30} \mathrm{~V}$ tejto súvislosti nezávislý vojenský analytik V. Muchin vo svojom článku „Armáda v službe ropného biznisu. Začínajúce vojenské cvičenia majú úplne nový kvalitatívny charakter" uvádza, že v tom čase prebiehajúce vojenské cvičenie (v Burjatsku, Sibírska oblast') v druhej polovici roku 2009 sú zamerané okrem iného aj na ochranu transportu energetických nosičov, pričom dodal, že otázkam ochrany transportných ciest pre ruský plyn do Európy po dne Baltského mora bude venované aj rozsiahle vojenské cvičenie „Západ 2009“ a „Ladoga 2009“. 31 V. Muchin sa taktiež domnieva, že OS RF by do budúcnosti mali plnit' praktické úlohy spojené nielen s vojenskou, ale aj ekonomickou bezpečnost'ou štátu, ktorá by mala nájst' svoje opodstatnenie aj v pripravovanej novej vojenskej doktríne. ${ }^{32}$

Na d’alší vývoj a smerovanie v reforme armády mala výrazný dopad aj vojenská operácia ruských ozbrojených síl v Gruzínsku v lete 2008, ktorá bola rozsiahlou čast'ou ruských vojenských odborníkov (A. Cygankov, P. Dejnekin, M. Gareev, P. Gračev, A. Chramčichin, A. Kortunov, V. Litovkin, V. Muchin, V. Mjasnikov, J. Netkačev) kritizovaná za spôsob jej prevedenia. ${ }^{33}$ Vojenská operácia RF v odštiepeneckých regiónoch Gruzínska (Južné Osetsko a Abcházsko) síce priniesla pomerne rýchle a l'ahké vojenské vít’azstvo ruskej armády, no na druhej strane odhalila chronické 
nedostatky, ktoré sú spojené predovšetkým s oblast'ou nových (staronových) trendov v oblasti moderného vedenia bojových operácií - t.j. používanie mimoriadne presných zbraňových systémov, nových prostriedkov spojenia, rozviedky a riadenia vojsk a metód bojovej prípravy. Po tejto operácii sa zdvihla vlna kritiky, ktorá vojenskú akciu ruských OS nielen odsúdila z politického, ale aj odborného hl'adiska. Túto reakciu využil súčasný ruský minister obrany Anatolij Serd'ukov na prípravu „d’alšej“ reformy (v skutočnosti však nedostatky vo vedení vojenskej operácie v Gruzínska boli len zámienkou na d’alšie štrukturálne a personálne zmeny v ruských OS, odstránenie l'udí bývalého ministra obrany Sergeja Ivanova a budovanie vlastnej názorovo blízkej skupiny). ${ }^{34} \mathrm{Na}$ základe plánu, ktorý predstavil A. Serd’jukov sa predpokladá, že k 1. decembru 2009 bude uvol'nených alebo prevelených na iné pozície a posty 140 tis. l’udí práporčíkov a mičmanov (poddôstojníkov vojenského námorníctva - pozn. autor). Ďalším ciel’om MO RF A. Serd'jukova je, aby do roku 2012 z celkového súčasného počtu 1107 generálov a admirálov zostalo v ozbrojených silách len 877 . Taktiež by sa mal znížit' stav centrálneho aparátu Ministerstva obrany RF a orgánov vojenského riadenia (správy), ktorí v súčasnosti predstavuje počet 21813 l'udí, a to až 2,5 násobne do celkového počtu maximálne 8,5 tisíc. Množstvo dôstojníkov varmáde má byt' optimalizované v porovnaní zo svetovými normami. Podl'a vyjadrenia A. Serdjukova, skúsenosti vo svete ukazujú, že množstvo dôstojníkov v armáde predstavuje od 7 do $20 \%$. $^{35}$ Ozbrojené sily RF by taktiež od roku 2012 mali prejst' na brigádnu štruktúru z doterajšej divízno-plukovej. ${ }^{36}$ Paralelne s týmto procesom by mala byt pripravená nová koncepcia rozvoja ozbrojených síl RF do roku 2030 a taktiež aj nová Vojenská doktrína RF. ${ }^{37}$ V ruských odborných kruhoch, ktoré sa zaoberajú už dlhší čas reformou spojenou s armádou (napr. Vitalij Cymbal, Pavel Fengengauer, Alexander Gol'c, Viačeslav Izmailov, Viktor Litovkin, Vladimír Muchin a d'alší) boli prezentované rozličné názory na formu a obsah doteraz realizovanej (a pripravovanej) vojenskej reformy, pričom v centre pozornosti bolo široké spektrum problémov s touto rozsiahlou úlohou spojených. Napriek radikálnym ciel’om urýchlit' reformu OS RF (ešte pred rokom 2012), niektorí analytici pochybujú o jej úspešnosti, a to nielen z hl'adiska nastaveného časového harmonogramu. Ako v tejto súvislosti uvádza Pavel Felgengauer, ,koncepcia reformy je správna, ozbrojené sily je nevyhnutné modernizovat', no predstavené plány sú nerealistické. Na jednej strane sú skrátené termíny pre vyplnenie úloh, na druhej strane nikto nevie čo bude v roku 2020, pretože čím dlhodobejšie termíny, tým vážnejšie sa javia plány ich realizácie. “ ${ }^{38}$ A. Arbatov v tomto kontexte ešte $\mathrm{v}$ roku 2003 upozorn̆oval, že minimálna lehota na uskutočnenie reformy ozbrojených síl je 10 až 15 rokov. ${ }^{39}$ Taktiež treba podotknút, že reformu OS RF nie je možné vnímat' iba v jej štrukturálnosti a personálnom zabezpečení, ale je nevyhnutné ju osadit' do širšieho spoločensko-politického a ekonomického kontextu.

Ako upozorňujú niektorí analytici, prebiehajúca vojenská reforma môže vytvorit' aj vnútropolitické problémy, nakol'ko súčasnú reformu OS RF je potrebné vnímat' v kontexte zmien zameraných na vnútornú modernizáciu Ruska, na ktorú kladie dôraz prezident D. Medvedev (aj ked' zatial' len v rétorickej rovine nakol'ko nemá vytvorené vlastnú názorovo silnú a dostatočne vplyvnú skupinu). Hlavné myšlienky spomínanej modernizácie boli publikované 10. septembra 2009 v stati „Rusko vpred“. V uvedenej stati D. Medvedev predstavil svoje názory, a zároveň ich zadefinoval ako budúce strategické úlohy RF. V stati sa okrem iného uvádza, že súčasná modernizácia by mala byt' dosiahnutá demokratickou cestou, založená na intelekte a technológiách, a nie na surovinovej základni. ${ }^{40}$ Zdôraznenie týchto kl'účových faktorov modernizácie RF sa stali základom aj jeho každoročného prejavu o stave RF 12 . novembra $2009,{ }^{41}$ a taktiež v rámci vystúpenia na zjazde provládnej strany „Jednotné Rusko“ 21. novembra 2009, kde opätovne hovoril o nevyhnutnosti všestrannej modernizácie RF, ktorá by mala byt' smerovat' k vybudovaniu poznatkovej (inovatívnej) a vysoko technologickej ekonomiky. ${ }^{42}$ Treba podotknút', že načrtnutý program D. Medvedeva je vo svojej podstate vo vnútornej disonancii s doteraz presadzovaným oficiálnym štátnym programom (ideológiou) premiéra V. Putina, známym aj ako tzv. „suverénna demokracia“. Termín „suverénna demokracia“ vznikol s ciel’om vypracovania novej štátnej ideológii zdôvodňujúcej vnútornú a zahraničnú politiku RF. V rámci tejto ideológie sa 
stalo nosnou myšlienkou posilnenie štátu a efektívnost’ jeho riadenia vo všetkých oblastiach politického, spoločenského, hospodárskeho a kultúrneho života. ${ }^{43}$ Modernizačný program D. Medvedeva však vychádza z demokratických (čiastočne liberálnych) postulátov, čo vyvoláva do budúcnosti viaceré otázky. Čo je však nemenej dôležité, obidva programy sa zhodujú vo viacerých ciel'och - okrem iného aj vo vybudovaní silných, efektívnych a akcieschopných OS RF, rozdielne sú však filozofické východiská týchto programov. V tejto súvislosti treba mat' na zreteli, že politika V. Putina vychádza (vychádzala) z preddispozície silného a centralizovaného štátu, ktorý je rozhodujúcim činitel'om v politickom a hospodárskom priestore. Zásadným štrukturálnym problémom uskutočnenia akejkol'vek vnútornej reformy (modernizácie) vrátane vojenskej sa môže do budúcnosti javit' práve charakter ruského štátu, spoločnosti a hospodárstva. Nasvedčuje to aj aktuálny spôsob pôsobenia štátu v ekonomike, ktorý je plne v súlade s koncepciou suverénnej demokracie, v rámci ktorej sa štát v hospodárskej sfére opiera o vlastné (ruské) - kapitálovo silné korporácie pôsobiace predovšetkým voblastiach t’ažby a prepravy ropy, zemného plynu, oceliarstva a spracovania nerastných surovín, zbrojného priemyslu, dopravy a infraštruktúry. Model integrácie (v skutočnosti však centralizácie) ropných a plynových koncernov do vel’kých korporácií $\mathrm{s}$ väčšinovým podielom štátu, sa v krátkodobej perspektíve ukázal byt' účinný, ale z dlhodobého hl'adiska predstavuje v podmienkach silnejúcej globalizácie neperspektívnu cestu. Obdobný model ovplyvňovania a kontroly ekonomiky prostredníctvom centralizácie kl’účových hospodárskych štruktúr sa ruské politické vedenie za predchodcu D. Medveda snažilo presadit' aj do ostatných odvetví (príkladom sú mamutie zjednotené korporácie, ktoré združujú výrobcov na základe príslušnosti k danému odvetviu - lietadiel, lodí, atómový a strojársky priemysel, a pod). ${ }^{44}$ Preto v uvedenom kontexte treba zohl'adňovat' skutočnost', že vojenská reforma priamo podmien̆uje aj reformu VPK. Doterajšie kroky, ktoré boli v oblasti reformy VPK realizované však vyvolávajú oprávnené pochybnosti o jej účelnosti a efektívnosti, ale aj o celkovom fungovaní VPK z hl'adiska jeho budúcnosti. Zásadným krokom sa v koncepcii reformy VPK (za druhého volebného obdobia prezidenta V. Putina) stalo vytvorenie štátnych holdingov, ktoré sa mali stat' základom obnoveného ruského VPK (celkovo sa na začiatku uvažovalo, že bude vytvorených až 50 holdingových spoločností a výskumných centier), a ktoré by v sebe mali koncentrovat', zachovávat' a rozvíjat' základné technológie výroby ruskej vojenskej techniky. Princíp formovania holdingov spočíva predovšetkým v tom, že na základe hlavných podnikov vyrábajúcich vojenskú produkciu sa vytvorí vedúca riadiaca spoločnost', v ktorej štát bude vlastnit' minimálne $51 \%$ akcií. Podniky, ktoré sú včlenené do holdingu sú akciovými spoločnost’ami, v ktorých vedúca riadiaca spoločnost' disponuje nie menej ako $51 \%$ akcií. ${ }^{45}$ Zdá sa však, že zriadenie štátnych holdingových korporácií neprinieslo očakávaný efekt, práve naopak pre ruský štát sa stali v kontexte finančnej krízy vel’kou zát’ažou. V posolstve FZ RF 12. novembra 2009 D. Medvedev na margo štátnych korporácií doslova vyhlásil, že považuje túto formu v súčasných podmienkach za bezperspektívnu. Taktiež vyjadril presvedčenie, že bude potrebné prehodnotit’ aj mieru účasti štátu v komerčnej sfére, ale aj proces priamej podpory podnikov, ktorý už v čase finančnej krízy presiahol trilión rubl'ov. Spoločnosti, ktoré sú neefektívne budú nutne musiet' prejst' ozdravným procesom alebo trh opustit' (týka sa to aj viacerých VPK). ${ }^{46}$ Kritické slová na adresu predstavitel’ov VPK vyslovil D. Medvede aj 26. októbra 2009 v podmoskovskej oblasti v Reutove kde navštívil vedecko-výskumný podnik „NPO Mašinostroenija“. Vyjadril vážne obavy so schopnost'ou podnikov VPK technicky prezbrojit’ a vystrojit' armádu a námorníctvo. Tvrdú kritiku vyslovil na kvalitu vojenskej produkcie, vysoký stupeň reklamácií (len $10 \%$ podnikov VPK má medzinárodne uznávaný certifikát kvality riadenia), neprimerane vysokú úroveň vlastných (vnútorných) nákladov podnikov VPK. Kritizoval, proces vyčleňovania finančných prostriedkov na modernizáciu morálne zastaranej techniky, alebo techniky, ktorá v krátkom čase bude zastaraná, na úkor ich presmerovania na vývoj a výskum novej vojenskej techniky a zbraňových systémov. ${ }^{47}$ Tieto slová len potvrdzujú známu skutočnost', že ruský vojenský priemysel má čoraz väčšie problémy udržat' technologickú úroveň s vyspelými štátmi sveta, pričom sa túto priepast' snaží riešit' aj dovozom zahraničnej vojenskej techniky, čo je na rozdiel od minulosti doslova revolúciou. ${ }^{48}$ 
Ciel'om prezidenta D. Medvedeva vo vojenskej oblasti je skončenie s dôsledkami sovietskeho obdobia, kedy sa armáda pripravovala k tradičnej „masívnej konvenčnej vojne“ v Európe a viac sa prispôsobit’ podmienkam budúcich možných regionálnych konfliktov. Práve s takýmto typom vojenských konfliktov sa môžu v budúcnosti OS RF stretnút'. Ako uvádza vojenský analytik Dmitrij Cybakov, problematickým z pohl'adu d'alšej realizácie vojenskej reformy sa môže javit' existencia názorovo silných - a vo svojej podstate protikladných skupín, vrátane intenzívne sa formujúcej opozičnej skupiny voči vojenskej reforme „Serd'ukova“, ktorých pôsobnost' je nevyhnutné chápat' aj v kontexte ruských organizovaných záujmov, nakol'ko politické elity sú nútené brat' názor „,voennych“ pri jej realizácii. ${ }^{49}$ Výhodou A. Serd’ukova sa ukazuje práve schopnost' v obmedzovaní partikulárnych záujmov armády, na rozdiel od jeho predchodcov (predovšetkým S. Ivanova). Ako uvádza P. Felgengauer „Serd’ukov má aj silnú podporu skupiny generálov, ktorí veria v reformu a chcú ju doviest’ do konca“. Liberálna skupina formujúca sa okolo súčasného ministra obrany A. Serd’ukova spája predstavu reformy OS RF nielen so štrukturálnymi a organizačnými reformami, ale predovšetkým s celkovou reformou v oblasti bojovej prípravy, velenia a riadenia.

Je logické, že rozsiahla a silná kritika vojenskej reformy pochádza predovšetkým z vnútra armády. Napr. v periodiku „Soldaty Rossii“" sa kriticky vyjadrujú k prebiehajúcej vojenskej reforme niektorí analytici, ale aj bývalí vysoko postavení armádni predstavitelia. Anatolij Cyganok riaditel' Centra vojenských prognóz, kritizoval prechod k trojúrovňovému systému riadenia (vojenský okruh - armáda - brigáda), ktorý v budúcnosti bude viest’ k zníženiu bojaschopnosti armády. Zároveň upozornil, že transformácia tyla OS RF do holdingu „Oboronservis“ vytvorí priestor pre rozsiahlu korupciu. Riešenie $\mathrm{v}$ tomto smere vidí vo vytvorení vládnej komisie pre kontrolu prebiehajúcej vojenskej reformy. ${ }^{50} \mathrm{~S}$ kritikou tylového zabezpečenia armády vystúpil aj Konstantin Sivkov, viceprezident Akadémie geopolitických problémov, upozorňujúc na skutočnost', že prenechanie tylového zabezpečenia $\mathrm{v}$ čase mieru civilným organizáciám, 14x predražilo celý jeho proces. Zároveň dodal, že takýto civilný tyl sa „rozbehne“ po prvom výstrele. ${ }^{51}$ Alexander Konoval'ov, prezident Inštitútu strategických hodnotení, vyjadruje pochybnosti s celkovým spôsobom diskusie vojenskej reformy v odbornej aj laickej verejnosti, resp. absencie relevantnej a odbornej diskusie o tak vážnom probléme akým nepochybne vojenská reforma je. Vitalij Šlykov - člen SVOP a člen Spoločenskej rady pri MO RF je jedným z najtvrdších kritikov vojenskej reformy. Sám predložil už viac ako 100 návrhov na zlepšenie stavu armády, pričom na základe štúdia a výskumov iných armád štátov, navrhol 15 všeobecných charakteristík ktoré sú platné u kvalitatívne fungujúcich armádach vo svete. ${ }^{52}$ U ruskej armády v súčasnosti z uvedených charakteristík nie je aplikovaná ani jedna, resp. začína sa s prípravou profesionálneho dôstojníckeho zboru. V. Šlykov ešte v marci 2009 v rámci vystúpenia na Vyššej škole ekonomiky v Moskve na seminári s názvom „Reforma Serd'ukova, vít’azstvo zdravého rozumu“ uviedol, že väčšinu krokov a opatrení, ktoré momentálne realizuje súčasné vedenie MO RF, odporúčali (SVOP - pozn. autor) ešte v roku 2004 vo svojom doklade „Vojenská výstavba a modernizácia ozbrojených síl Ruska“. ${ }^{53}$ Leonid Ivašov, prezident Akadémie geopolitických problémov, pripomína že od roku 1998 sa uskutočnilo 6 etáp vojenskej reformy, pričom všetky začali a zároveň skončili pri otázke redukcie vojakov a vojenského personálu. ${ }^{54}$ Medzi tvrdých kritikov prebiehajúcej vojenskej reformy sa zarad'uje aj bývalý MO RF Igor Rodionov, ktorý vidí za uvedenou reformou oslabenie a zničenie Ruska, a je ho možné zaradit' medzi čast' ruskej generality, ktorá je svojim bezpečnostným konceptom fixovaná na možnú konfrontáciu s armádami NATO. Táto konzervatívno-kritická skupina taktiež zastáva názor, že reforma armády sa má uberat' takým smerom, aby mohla do budúcnosti čelit’ masívnemu konvenčnému útoku. ${ }^{55}$

To aké bude budúce zameranie a smerovanie ruskej armády, resp. na plnenie akých úloh by mala byt' pripravená je možné vydedukovat' aj z pripravovanej novej vojenskej doktríny, ktorá podl'a preniknutých a na verejnosti zverejnených informácií (rozhovor s tajomníkom Bezpečnostnej rady RF N. Patruševom) predpokladá pružné, včasné a vhodné reagovanie na prebiehajúce a perspektívne zmeny vojensko-politickej a vojensko-strategickej situácie 
v strednodobej perspektíve. ${ }^{56}$ Vojenské konflikty by mala nová vojenská doktrína rozdel'ovat' podl'a intenzity na rozsiahle, regionálne, lokálne a ozbrojené konflikty (medzištátne aj vnútroštátne). Dôležitým aspektom, o ktorom sa v tejto súvislosti N. Patrušev zmienil je úloha jadrových zbraní v ruskom vojensko-bezpečnostnom plánovaní. Pri tejto príležitosti nevylúčil aj možnost' preventívneho jadrového útoku proti agresorovi v kritických situáciách pre národnú bezpečnost'. Prípadné použitie jadrových zbraní by v novej vojenskej doktríne malo byt' rozšírené aj na regionálne a lokálne vojenské konflikty. Otázka jadrových zbraní v novej vojenskej doktríne bude ponímaná $v$ duchu zachovania statusu jadrovej vel'moci. ${ }^{57}$ Aspekt jadrových zbraní a ich dôležitost' je jednou z konštant, na ktorej sa zhodujú odporcovia aj zástancovia vojenskej reformy, pričom ako v tomto smere poznamenáva P. Felgengauer, s výnimkou Severnej Kórei a Iránu vo svete dnes nikto iní jadrové zbrane nevyvíja. Rozvoj jadrových síl je sama o sebe drahá záležitost', preto je zložité túto úlohu spájat' s rozvojom (reformou) armády. ${ }^{58}$ Pri súčasnom stave OS RF zostáva spoliehanie sa na použitie jadrových zbraní v prípade ohrozenia vlastnej bezpečnosti jediným zo spôsobov zabezpečenia svojej bezpečnosti. To je však implicitne spojené s existenciou priamej hrozby vojenského charakteru, t.j. vojenského útoku na RF, ktorý je aj podl'a ruských bezpečnostných analytikov momentálne nepravdepodobný (t’ažko si predstavit' použitie jadrových zbraní v boji proti teroristom, ale aj $\mathrm{v}$ niektorom existujúcom alebo potenciálnom konfliktnom mieste napr. postsovietskeho priestoru).

\section{ZÁVĚR}

Pre viacerých analytikov (predstavujú vyššie uvedené plány MO RF doslova radikálne zmeny. Napriek tomu, že po ich avizovaní sa ozývajú silné kritické hlasy, ktoré upozornili, že v danom rozsahu bude uvedená reforma viest' k rozvrat ruských ozbrojených síl, si treba uvedomit', že d'alšie pôsobenie OS RF bude v budúcnosti závisiet' od jej skutočnej (súčasnej) pripravenosti reagovat' na nové bezpečnostné výzvy a hrozby, s ktorými sa bude RF a jej vojensko-bezpečnostné zložky a aparát v nasledujúcich rokoch konfrontovat'. Potreba reformy je teda dôsledkom nielen zmenenej medzinárodnej vojensko-politickej situácie a technologickej revolúcie, ktorá v tomto smere neuskutočnenie, resp. odd'al'ovanie vojenskej reformy už d'alej nepripúšt’a, ale v neposlednom rade sú to aj ekonomické aspekty, ktoré ju robia bezalternatívnou.

Na d'alší priebeh vojenskej reformy bude nepochybne vplývat' predovšetkým politická vôl’a ju vôbec dokončit', a nezastat' na polceste alebo ju ,utopit“" v množstve kompromisov alebo kozmetických úprav tak ako tomu bolo $\mathrm{v}$ minulosti, ktoré by $\mathrm{v}$ konečnom dôsledku viedli k d’alšiemu prehlbovaniu už i tak komplikovanej situácie celého vojenského sektoru.

Pokial' ide o širší zahranično-politický kontext, je potrebné v závere uviest', že ruská bezpečnostná politika prešla počas svojho krátkeho obdobia po rozpade ZSSR relatívne krátku cestu, v rámci ktorej je možné v doterajšom procese jej vývoja vygenerovat' znaky dostatočným spôsobom ju charakterizujúce a profilujúce. Jej obsahovú štruktúru v súčasnosti predstavuje súhrn viacerých faktorov, predovšetkým však historických, politických, vojenských, ekonomických, kultúrnych a geografických. Napriek transformácii bezpečnostného prostredia a zmene optiky na problematiku bezpečnosti zostáva ruskej bezpečnostnej politike a vojenskému plánovaniu signifikantný vlastný, špecifický pohl'ad a prístup, čo je spôsobené na jednej strane objektívnymi faktormi, kedy bezpečnostná politika RF riešila otázky, ktoré boli hlboko poznamenané jednak zmenenými medzinárodno-právnymi okolnost’ami, jednak vnútornou transformáciou ruského štátu, ale na druhej strane subjektívnymi a psychologickými faktormi reprezentujúcimi historickú skúsenost' a reminiscencie. 


\section{POZNÁMKY}

${ }^{1}$ PEARSON, Frederick, ROCHESTER, Martin. Medzinárodné vzt'ahy, s. 89.

${ }^{2}$ FRANK, Libor. Bezpečnostní politika, s. 134.

${ }^{3}$ Zakon o bezopasnosti z 22.11.1992, s. 2.

${ }^{4}$ BALABÁN, Miloš. Potenciál ruské armády jako mocenského faktoru v ruské politice, s. 27.

${ }^{5}$ Napriek tomu RF stále kladie vel'ký dôraz na svoj jadrový potenciál a schopnost' zasadit' zničujúci úder Spojeným štátom. Taktiež A. Duleba sa domnieva, že strategickým ciel’om RF v oblasti jadrovej bezpečnosti je vrátit' USA spät' do zmluvného systému, ktorý by bol rovnocenný zmluve ABM.

${ }^{6}$ KOLEKTIV, autorov. Nacionalnie interesy i problemy bezopasnosti Rossii, s. 18.

${ }^{7}$ BALABÁN, Miloš. Putin a Ruská armáda v poločase, s. 11-12.

${ }^{8}$ FELGENGAUER, Pavel. Russian military reform: Ten years of failure.

9 DULEBA, Alexander, HIRMAN, Karel. Rusko na konci Jel'cinovej éry. Zahraničná a vnútorná politika,rozširovanie NATO a záujmy Slovenska, s. 19.

10 INSTITUT NACIONALNOJ BEZOPASNOSTI I STRATEGIČESKICH ISSLEDOVANIJ. Voennaja reforma v RF: vychod na praktičeskij uroven̆ trebuet utočnenija celej i vozmožnostej, s. 4-6.

${ }_{11}$ INSTITUT NACIONALNOJ BEZOPASNOSTI I STRATEGIČESKICH ISSLEDOVANIJ. Voennaja reforma v RF: vychod na praktičeskij uroveň trebuet utočnenija celej i vozmožnostej, s. 9.

${ }_{12}$ Medzi novinárov prezentujúcich rusko-čečenskú vojnu ako záujmový konflikt (na rozdiel od hodnotového), v ktorom išlo predovšetkým o legalizáciu príjmov z kriminálnych aktivít (únosy, odpredávanie „zmiznutých“ zbraní), ale aj transport kaspickej ropy, patril okrem Chlebnikova, Politkovskej aj Felgengauer.

${ }^{13}$ Vojenské okruhy (VO) RF: Moskovský VO, Severokaukazský VO, Leningradský VO, Privolžský VO, Uralský VO (V súlade s Výnosom prezidenta RF №337-s z 24. marca 2001, 1. septembra vznikol spojením Privolžského a Uralského VO Privolžsko-uralský VO), Sibírsky VO, Zabajkalský VO (Zabajkalský VO bol 1. decembra 1998 pripojený k Sibírskemu VO), Dalekovýchodný VO. Kaliningrad je definovaný ako špeciálny región.

${ }_{14}$ Medzi základné doktrinálne dokumenty tohto obdobia patria: Koncepcia národnej bezpečnosti Ruskej federácie z 10. januára 2000; Základy politiky Ruskej federácie v oblasti vojensko-námornej činnosti do roku 2010 - 4. 3. 2000; Vojenská doktrína Ruskej federácie z 21. apríla 2000; Koncepcia zahraničnej politiky Ruskej federácie z 28. júna 2000 a jej aktualizovaná verzia z 15. júla 2008; Doktrína informačnej bezpečnosti Ruskej federácie z 9. septembra 2000; Aktuálne úlohy rozvoja ozbrojených síl Ruskej federácie z 2. októbra 2003.

${ }^{15}$ RYBKIN, Ivan. Neobchodim celostnij vzgljad na nacionalnie interesy gosudarstva, s. 3.

${ }^{16}$ Voennaja doktrina Rossijskoj Federacii, s. 4.

${ }^{17}$ PUTIN, Vladimir. Skončila sa revolúcia, začína sa budovanie, s. 57.

${ }^{18}$ FELGENGAUER. Pavel. Rossijskaja armija - armija dezertirov.

${ }^{19}$ Aktualnye zadači razvitja vooružennych sil Rossijskoj Federacii, s. 22.

${ }^{20}$ DOLINAY, Juraj. Ruská armáda na križovatke, s. 4.

${ }^{21}$ EICHLER, Jan. Mezinárodní bezpečnost a počátku 21. století, s. 215-217.

${ }^{22}$ ARBATOV, Alexej, Grigorievič. Kontury rossijskoj voennoj reformy, s. 13.

${ }^{23}$ ORR, Michael. Ruské ozbrojené sily ako faktor regionálnej stability, s. 118.

${ }^{24}$ Bližšie pozri interview pri prezentáciu dokladu: http://www.svop.ru/live/news.asp?n_id=8361.

${ }^{25} \mathrm{~V}$ tomto smere boli na oficiálnej úrovni krátko po nástupe V. Putina $\mathrm{k}$ moci prejednávané - v máji 2000 v RB RF projekt „Základy štátnej politiky RF v oblasti vojenskej výstavby na obdobie do roku 2010“. V auguste 2000 RB RF posúdila „Stratégiu vojenskej výstavby v Rusku do roku 2015“, vychádzajúc z dokumentov „Stav ozbrojených síl RF a hlavné smery ich výstavby a vývoja do roku 2010“ a „Návrh koncepcie vývoja výzbroje a vojenskej techniky do roku 2015“. Uvedenie týchto dokumentov do reálnej praxe však vychádzalo neraz z príliš optimistických východiskových pozícií a neakceptovalo reálne možnosti ruskej ekonomiky, resp. ruského štátu.

${ }^{26}$ FELGENGAUER, Pavel. Military doctrine or election manifesto. The Ivanov Doctrine, s. 2.

${ }^{27}$ Aktualnyje zadači Vooruženych Sil Rossijskoj Federacii, s. 3.

${ }^{28}$ LASICOVÁ, Jana. Bezpečnost'. Bezpečnostná agenda súčasnosti, s. 149.

${ }^{29}$ LIAROPOULOS, Andrew. The Russian defense reform and its limitations, s. 7.

${ }^{30}$ Strategia nacionalnoj bezopasnosti Rossijskoj Federacii do 2020 goda, s. 2. 
${ }^{31}$ V skutočnosti ide o formálne rozdelenie rozsiahlych vojenských manévrov na dve časti (Ladoga 2009 a Západ 2009), z dôvodu aby počet vojakov nepresiahol 13 tis., čo by si vyžadovalo aj prizvanie zahraničných pozorovatel'ov.

${ }_{32}$ MUCHIN. Vladimir. Armija na službe neftebiznesa. Načavšiesja voennie manevry nosjat sovremenno novyj kačestvennyj charakter, s. 1-2.

${ }^{33}$ MELKOV, Sergej. Vooružennyj konflikt v Južnoj Osetii: katalizator voennogo reformirovania v Rossii?

${ }^{34} \mathrm{~V}$ súvislosti s plánmi vojenskej reformy sa v RF priamo hovorí aj o tzv. „kádrovej revolúcii“, ktorá de facto vyvrcholila 3. júna 2008 odvolaním generála Jurija Balujevskeho - náčelníka Generálneho štábu RF, ako najdôležitejšie inštitúcie predstavujúcej tzv. „generálsku opozíciu“ voči civilnému ministrovi obrany RF A. Serd’ukovovi. Okrem toho boli predtým odvolaní alebo „iným“ spôsobom ukončili vojenskú službu (dosiahnutie služobného veku, dobrovol’ný odchod, preradenie na inú pozíciu) napr. bývalý šéf vojenskej rozviedky (GRU) Valentín Korabelnikov, velitel' leteckých síl (VVS) Vladimír Michajlov, velitel' ruského námorníctva (VMF) Vladimír Masorin, náčelník motostreleckých jednotiek Vladimil Polonskij a iní. Vlnu kritiky v armádnych kruhoch vyvolal taktiež presun štábu vojenského námorníctva z Moskvy do Petrohradu.

${ }^{35} \mathrm{~V}$ súčasnosti je v ruskej armáde 355 tis. dôstojníkov, čo predstavuje $32 \%$ z celkového počtu. Do roku 2012 toto číslo nemá prevyšovat' 150 tis. z celkového počtu 1 milión osôb (t.j. maximálne $15 \%$ ). Taktiež by mal byt' v rovnakom čase, t.j. do roku 2012 optimalizovaný systém vojenského vzdelávania. Existujúcich 15 akadémií, 4 vojenské univerzity a 46 vojenských inštitútov a učilíšt bude reštrukturalizovaných na 10 vzdelávacích vysokých škôl - t.j. 3 vojenských učebno-vedeckých centier, 6 vojenských akadémií a 1 vojenská univerzita. Podl'a zámerov MO RF, tieto by mali riešit' nielen úlohy spojené s prípravou a výučbou nových dôstojníckych kádrov, ale mali by viest' aj vedecko-výskumnú prácu. Predpokladá sa však, že personálna zostava pedagógov bude zachovaná.

${ }^{36}$ SOLOVJEV, Vadim. Voennaja reforma 2009-2012 godov.

37 Prvé informácie o príprave týchto dokumentov boli zverejnené v ruských masovokomunikačných prostriedkoch začiatkom augusta 2008, resp. decembra 2008.

${ }^{38}$ SAMIGULINA, Alija. Voennaja reforma v rassročku.

${ }^{39}$ ARBATOV, Alexej, Grigorievič. Kontury rossijskoj voennoj reformy, s. 2.

${ }^{40}$ MEDVEDEV, Dmitrij. Rossija vpered!

${ }^{41}$ Poslanie Federalnomu Sobraniju Rossijskoj federacii.

${ }^{42}$ Pri tejto príležitosti bola ešte v priebehu roka 2009 zriadená pri prezidentovi RF Komisia pre modernizáciu a technologický rozvoj ekonomiky RF. Na svojom poslednom zasadnutí dňa 25. novembra 2009 D. Medvedev vyjadril presvedčenie o tom, aby členmi tejto komisie boli okrem iných aj ruské spoločnosti a korporácie Rosnano (korporácia zaoberajúca sa otázkami nanotechnológií) a Vnešekonombank.

${ }^{43}$ DULEBA, Alexander. Ruská federácia pred prezidentskými volbami 2008, s. 26.

${ }^{44}$ Významné postavenie a pozície hospodárskych koncernov (palivovo-energetických monopolov, vojenskopriemyselného komplexu, ekonomicko-finančnej lobby, prerastanie ekonomickej štruktúry do politickej a naopak) v ruskej politike a spoločnosti vôbec naznačujú latentný, ale silný korporativizmus v jeho politickom systéme.

${ }^{45}$ HOREMUŽ, Martin. Ruský vojensko-priemyselný komplex a jeho miesto a úloha v politickom systéme Ruska, s. 94.

${ }^{46}$ Poslanie Federalnomu Sobraniju Rossijskoj federacii.

${ }^{47}$ LITOVKIN, Viktor. Glavkoverch vstrjachnul oboronnyj kompleks.

${ }^{48}$ Príkladom je prerušenie nákupu bezpilotných lietajúcich prostriedkov od domácich (ruských) výrobcov, a uprednostnenie nákupu takýchto strojov od Izraela (aj v dôsledku vojny v Gruzínsku v lete 2008). V tejto súvislosti dokonca vrchný velitel' vzdušných síl Anatolij Zelin vyhlásil, že kupovat' bezpilotné prieskumné lietadlá od domácich výrobcov s nevyhovujúcimi technicko-taktickými charakteristikami by bol prosto zločinom. Taktiež uvažovaný nákup francúzskej vojnovej lode triedy Mistral (a ich neskoršia licenčná výroba v RF) pre potreby transportu vojenskej techniky a vojakov pre účely výsadku, signalizuje problémy domáceho VPK, a ich neschopnost' vyprodukovat' na kvalitatívne požadovanej úrovni bojovú techniku potrebnú pre OS RF.

${ }^{49}$ CYBAKOV, Dmitrij. Narastanie aktivnosti oppozicionnych veteranskich organizacij - itog «reformy Serdjukova»?

${ }^{50}$ V RF je vytváranie „komisií “ a „výborov“ už tradične zaužívaným byrokratickým rituálom a zároveň všeliekom na riešenie akýchkol'vek problémov.

${ }^{51}$ Autor neuvedený. Experty o reforme armii. 
${ }^{52}$ Medzi tieto body zaradil okrem iného: profesionálny dôstojnícky zbor; existencia v mierovom období štruktúr spájajúce rôzne vojenské jednotky a prostriedky; prísna parlamentná a občianska kontrola obranného rozpočtu; absencia prinútenia súkromnej sféry v čase mieru k podpore vojenskej mobilizácie; podriadenie vnútorných vojsk ministerstvu obrany; podriadenie vojenskej rozviedky civilnému ministerstvu obrany a nie generálnemu štábu; existencia vlastnej kontrarozviedky v ozbrojených silách; teritoriálny a územný princíp dopíňania materiálneho vybavovania armády; neexistencia špeciálnych vzdelávacích inštitúcií pre vojenských právnikov, medikov, žurnalistov a kňazov; absencia inštitútu zástupcu velitel'ov pre výchovnú prácu.

${ }_{53}^{53}$ MELKOV, Sergej. Vooružennyj konflikt v Južnoj Osetii: katalizator voennogo reformirovania $v$ Rossii?

${ }^{54}$ Autor neuvedený. Experty o reforme armii.

55 Príkladom môže byt' rozsiahle vojenské cvičenie „Západ 2009“, ktoré ruská armáda uskutočnila v Kaliningrade a Bielorusku spolu s bieloruskými ozbrojenými silami. Toto cvičenie svojim rozsahom a zameraním vyvolalo v Pol'sku silnú kritiku a pobúrenie a to z dôvodu údajného simulovania jadrového útoku a invázie do Pol'ska. V tejto súvislosti aj litovský minister obrany Rasa Juknevičien vyhlásil, že hoci nešlo o priamu hrozbu voči Litve, tieto cvičenia nezodpovedajú realite a pripomínajú studenú vojnu.

${ }_{56}$ Medzi dôležitú indíciu, ktorá naznačuje smerovanie novej VD RF, je možné spomenút' aj v septembri 2009 prerokovávaný návrhu zákona o bezpečnosti, konkrétne časti 10, v ktorej prezident D. Medvedev navrhol doplnit' ustanovenie, týkajúcich sa ciel’ov ochrany záujmov RF a jej občanov, podpore medzinárodného mieru a formovania bezpečnosti, pri ktorej OS RF môžu operatívne používat' za hranicami RF vojenskú silu v súlade so všeobecnými princípmi a normami medzinárodného práva, medzinárodnými dohovormi, ktorými je RF viazaná pri riešení nasledovných úloh: Odvrátenie útoku na ozbrojené sily RF alebo iné vojská dislokované mimo teritória RF; Odrazenie alebo odvrátenie agresie proti inému štátu; Ochrana občanov RF za hranicami; Boj s pirátstvom a zabezpečenie bezpečnosti plavby ruských lodí. Tri zo štyroch týchto doplňujúcich bodov de facto opisujú stav a situáciu, ktorá vznikla v odštiepeneckých gruzínskych regiónoch Južné Osetsko a Abcházsko v lete 2008 - pravda z ruského uhl’u pohl’adu, a v tomto kontexte slúžia nielen na legalizáciu a legitimizovanie uskutočnenej vojenskej operácie, ale zároveň vytvárajú do budúcnosti právny rámec pre vojenské zásahy v iných častiach postsovietskeho priestoru.

${ }^{57}$ PATRUŠEV, Nikolaj. Neisklučaetsja nanesenie jadernovo udara.

${ }^{58}$ SAMIGULINA, Alija. Voennaja reforma v rassročku.

\section{LITERATURA}

[1] Aktual’nyje zadači razvitija Vooružennych sil Rossijskoj Federacii. Doklad Ministerstva oborony RF. Moskva: Voeninform, 2003. s.103. ISBN neuvedené.

[2] ARBATOV, Alexej. Kontury rossijskoj voennoj reformy. Rossija v globalnoj politike. 2003. roč. 2, č. 1, s. 1-19. ISSN 1810-6439.

[3] BALABÁN, Miloš. Potenciál ruské armády jako mocenského faktoru v ruské politice. Mezinárodní politika. 1999, roč. XXIII, č. 4, s. 27-30. ISSN 0543-7962.

[4] BALABÁN, Miloš. Putin a Ruská armáda v poločase. Mezinárodní politika. 2003, roč. XXVII, č. 8, s. 11-12. ISSN 0543-7962.

[5] CYBAKOV, Dmitrij. Narastanie aktivnosti opozicionnych veteranskich organizacij - itog «reformy Serd'jukova»? [online]. 2009. [cit. 2009-10-12]. Dostupné na internete: $<$ http://milpol.ru/data/2009/10_10/2.doc>.

[6] DOLINAY, Juraj. Ruská armáda na križovatke. Armáda. 2002, č. 4, s. 4-5. ISSN neuvedené.

[7] DULEBA, Alexander, HIRMAN, Karel. Rusko na konci Jel'cinovej éry. Zahraničná a vnútorná politika, rozširovanie NATO a záujmy Slovenska. Bratislava: Inštitút pre verejné otázky, 1999. 321 s. ISBN 80-88935-10-5.

[8] DULEBA, Alexander. Ruská federácia pred prezidentskými vol'bami 2008 [online]. 2008. [cit. 2009-11-24]. Dostupné na internete: <http://www.sfpa.sk/dokumenty/publikacie/214>. 
[9] EICHLER, Jan. Mezinárodní bezpečnost na počátku 21. století. Praha: AVIS, 2006. 303 s. ISBN: 70-7278-326-2.

[10] Experty o reforme armii [online]. Soldaty Rossii, 2009. [cit. 2009-07-14]. Dostupné na internete: 〈http://is.park.ru/doc.jsp?urn=19936710>.

[11] FELGENGAUER, Pavel. Military doctrine or election manifesto? The Ivanov Doctrine. [online]. Perspective Vol. XIV, No. 2 [cit. 2009-11-11]. Dostupný z WWW: <http://www.bu.edu/iscip/vol14/felg.html>.

[12] FELGENGAUER, Pavel. Russian military reform: Ten year of failure. [online] Moscow: Sevodnya newspaper, 2009. [cit. 2009-05-09]. Dostupný z WWW: <http://www.fas.org/nuke/guide/russia/agency/Felg.htm>.

[13] FELGENGAUER, Pavel. Rossijskaja armija. Armija dezertirov. The Christian science monitor, [online] 2002, [cit. 2009-08-22]. Dostupný zWWW: <www.inosmi.ru/untitled/20020930/159802.html >.

[14] FRANK, Libor. Bezpečnostní politika. In ZEMAN, Petr. (ed.): Česká bezpečnostní terminologie. Výklad základních pojmů. Brno: Masarykova univerzita, Mezinárodní politologický ústav a Ústav strategických studií Vojenské akadémia v Brne, 2002. s. 134-140. ISBN 80-210-3037-2.

[15] HOREMUŽ, Martin. Ruský vojensko-priemyselný komplex, jeho miesto a úloha v politickom systéme Ruskej federácie. Politické vedy. 2008, roč. XI, č. 1-2, s. 76-102. ISSN 1335-2741.

[16] INSTITUT NACIONALNOJ BEZOPASNOSTI I STRATEGIČESKICH ISSLEDOVANIJ. Voennaja reforma $v R F$ : vychod na praktičeskij uroveñ trebujet utočnenija celej i vozmožnostej. Institut nacional'noj bezopasnosti i strategičeskich issledovanij, Moskva 1999. [xerox kópia - archív autora].

[17] IPOLITOV, Ksenofont. Ideologija nacionalnoj bezopasnosti (Metodologija problemy). Moskva: Informacionno-analitičeskij centr Rossijskovo sojuza predprijatij, 1997. $120 \mathrm{~s}$. [xerox kópia - archív autora].

[18] KENNAWAY, Andrey. Súčasný stav ruského hospodárstva. In DICK, Charles, ALDIS, Anne (eds.). Stredná a východná Európa: Problémy a perspektívy. Bratislava: Slovenský inštitút medzinárodných štúdií, 2000. s. 87-102. ISBN 80-968224-3-8.

[19] KRČ, Miroslav, et al. Vojenské výdaje v letech studené války a po jejím skončení. Praha: Ústav mezinárodních vztahů, 2000. 192 s. ISBN 80-85864-93-2.

[20] KOLEKTÍV, autorov. Nacionalnie interesy i problemy bezopasnosti Rossii. Doklad po itogam issledovanija, provedennovo Centrom global'ny programm Gorbačev-Fonda v 1995-1997 gg. Moskva 1997. [archív autora - xerox kópia].

[21] LASICOVÁ, Jana. Bezpečnost’. Bezpečnostná agenda súčasnosti. Fakulta politických vied a medzinárodných vzt’ahov. UMB Banská Bystrica, 2006. 162 s. ISBN 80-8083-352-4.

[22] LIAROPOUlOS, Andrew. The Russian Defense Reform and its Limitations. Caucasian review of international affairs. [online]. Winter 2008, Vol. (2) 1. [cit. 2009-10-26]. Dostupný z ZWW: <http://criaonline.org/Journal/2/Russian\%20defence\%20reform\%20and\%20its\%20limitations $\% 20$ by $\%$ 20Liaropoulos_done.pdf>.

[23] LITOVKIN, Viktor. Glavkoverch vstrjachnul oboronnyj kompleks. Nezavisimaja gazeta [online]. 2009, [cit. 2009-10-30]. Dostupný z WWW: <http://nvo.ng.ru/realty/2009-1030/1_glavkoverh.html>. 
[24] MEDVEDEV, Dmitrij. Rossija vpered. Gazeta.ru [online]. 2009, roč. XI. [cit. 2009-11-28]. Dostupný z WWW: <http://www.gazeta.ru/comments/2009/09/10_a_3258568.shtml>.

[25] MEL'KOV, Dmitrij. Vooružennyj konflikt v Južnoj Osetii: katalizator voennovo reformirovanija v Rossii? [online]. [cit. 2009-11-28]. Dostupný z WWW: $<$ http://portal.rea.ru/portal/Main.nsf/0/62539C99649FBE0CC32575D900477627!OpenDocu ment>.

[26] MUCHIN, Vladimir. Armija na službe neftebiznesa. Načavšiesja voennie manevry nosjat sovremenno novyj kačestvennyj charakter. [online]. 2009 [cit. 2009-11-28]. Dostupný z WWW: 〈http://milpol.ru/data/2009/15_08/4.doc>.

[27] ORR, Michael. Ruské ozbrojené sily ako faktor regionálnej stability. In DICK, Charles, ALDIS, Anne (eds.). Stredná a východná Európa: Problémy a perspektívy. Bratislava, Slovenský inštitút medzinárodných štúdií, 2000. s. 115-128. ISBN 80-968224-3-8.

[28] PATRUŠEV, Nikolaj. Neiskl'učaetsja nanesenie jadernovo udara. Vzgljad. Delovaja gazeta [online]. 2009 [cit. 2009-10-21]. Dostupný Z WWW: <www.vz.ru/politics/2009/10/14/337666.html>.

[29] PEARSON, Frederick, ROCHESTER, Martin. Medzinárodné vzt’ahy. Bratislava: Iris, 1992. 271 s. ISBN 80-88778-42-5.

[30] Poslanie Federal'nomu Sobraniju Rossijskoj federacii. [online]. Prezident Rossii oficial'nnyj sajt, 2009 [cit. 2009-11-12]. Dostupný z WWW: <http://www.kremlin.ru/transcripts/5979>.

[31] PUTIN, Vladimir. Skončila sa revolúcia, začína sa budovanie. Fórum občianskej spoločnosti. 2000, roč. neuvedené, č. 12, s. 56-58. ISSN 1335-2296.

[32] RYBKIN, Ivan. Neobchodim celostnyj vzgljad na nacional'nie interesy gosudarstva. Nezavisimaja gazeta, [online]. [cit. 2002-09-10]. Dostupný z WWW: <http://www.ng.ru_ 1998-1-29>.

[33] SAMIGULLINA, Alija. Voennaja reforma v rassročku. Gazeta.ru, [online]. 2009 [cit. 200909-10]. Dostupný z WWW: <http://www.gazeta.ru/politics/2009/03/17_a_2959431.shtml>.

[34] SOLOVJEV, Vadim. Voennaja reforma 2009-2012 godov. Nezavisimoje voennoje obozrenie, [online]. 2009 [cit. 2009-07-11]. Dostupný z WWW: <http://nvo.ng.ru/forces/2008-12-12/1_reform.html>.

[35] Strategia nacional'noj bezopasnosti Rossijskoj federacii do 2020 goda [online]. Sovet bezopasnosti Rossijskoj Federacii, 2009 [cit. 2009-07-11]. 2 s. Dostupný z WWW: <http://www.scrf.gov.ru/documents/99.html>.

[36] Voennaja doktrina Rossijskoj federacii [online]. Sovet bezopasnosti Rossijskoj Federacii, 2000 [cit. 2009-07-11]. 4 s. Dostupný zWWW: <http://www.scrf.gov.ru/documents/33.html>.

[37] VYKOUKAL, Jiří et al. Východ. Vznik, vývoj a rozpad sovětského bloku 1944. Praha: Libri. 2000. 860 s. ISBN 80-85983-82-6.

[38] Zakon o bezopasnoti [online]. Sovet bezopasnosti Rossijskoj Federacii, 2000 [cit. 2009-0703]. 4 s. Dostupný z WWW: <http://www.scrf.gov.ru/documents/20.html>. 